\title{
Characteristics of Selected Peatland Uses and Soil Moisture Based on TVDI
}

\author{
Holidi $^{1,2}$, M Edi Armanto ${ }^{3}$, Nurhayati Damiri ${ }^{3}$, Dinar Dwi Anugerah Putranto ${ }^{4}$ \\ 1 Study Program of Environmental Science, Sriwijaya University, South Sumatera, Indonesia \\ 2 Faculty of Agriculture, Musi Rawas University, South Sumatra, Indonesia \\ 3 Faculty of Agriculture, Sriwijaya University, South Sumatra, Indonesia \\ ${ }^{4}$ Faculty of Engineering, Sriwijaya University, South Sumatra, Indonesia \\ * Corresponding author's e-mail: holidiman@yahoo.co.id
}

\begin{abstract}
The conversion of peatland from forest to non-forest causes environmental damage and increases high land dryness. Mapping of peatland based on dryness is very important to control and prevent fires. This study aims at characterizing peatland based on the level of temperature vegetation dryness index (TVDI) and evaluating the correlation between TVDI value and soil moisture. The research was conducted in August 2018 during the dry season. The area of research located in peat hydrological unit of Sibumbung River - Batok River in Ogan Komering Ilir (OKI) District of South Sumatra Province covering 63,427 ha area that consists of various land uses. The result showed that extreme wet category is found in water bodies and secondary forests that have high density, moderate wet is found in paddy fields and grass, normal area is found in the area covered by low-density trees, moderate dry is found in shrubs and oil palm plantations with good management and extreme dry areas is found in grasses and oil palm with poor cultivation management. There is a correlation between the TVDI value to the soil moisture on 0-10 $\mathrm{cm}$ and $10-20 \mathrm{~cm}$ and $20-30 \mathrm{~cm}$ depth.
\end{abstract}

Keywords: remote sensing, land use, drought, fire, South Sumatra

\section{INTRODUCTION}

Peat was formed from the accumulation of organic material in a long time in the past. This accumulation occurs because the decomposition rate is slower than the production rate The growth rate of forest biomass in peatland reaches 5 tons/ ha/year [Englhart et al., 2015; Osaki et al., 2016].

The peatland conversion in Southeast Asia reaches 47.6 percent of total 12.9 million hectares [Hooijer et al., 2010], whereas in the Sumatra region degradation reaches 29.5 percent of the total 1.25 million hectares [Miettinen and Liew, 2010]. One of the impacts resulting from the conversion is drought due to draining land for agricultural cultivation purposes [Arshad and Armanto, 2012; Lim et al., 2012; Holidi et al., 2014]. This condition has increased vulnerability to peat fires, especially during the dry season [Kirana et al., 2016].
Landsat 8 produces a satellite image with $30 \mathrm{~m}$ resolution for multispectral bands and $15 \mathrm{~m}$ resolution for panchromatic bands. The combination of bands from Landsat 8 can be used to interpret land uses and to calculate the NDVI [Acharya and Yang, 2015]. TVDI uses NDVI and land surface temperature (LST), it helps to identify the level of soil drought [Chen et al., 2011, 2015]. However, the utilization of TVDI to observe drought of peat with various land uses is still limited. The level of land drought will be related to the fire risk of the land.

TVDI is an index based on the relationship between the land surface temperature and the vegetation index that can be used to predict surface moisture. In the area with higher vegetation index, Land Surface Temperature (LST) is very sensitive to the water pressure resulting from the relationship between canopy temperature and 
transpiration. In the lower areas vegetation index, LST is determined by the soil moisture variation through evaporative control and thermal inertia [Du et al., 2017. Schirmbeck, 2017].

Mapping of peatland based on dryness is very useful to monitor and prevent fires. Peatlands in Ogan Komering Ilir District, South Sumatra Province of Indonesia is an area with a high fire risk and studying it is very important .

\section{Methods}

The research was conducted on Peat Hydrological Unit of Sibumbung River-Batok River Ogan Komering Ilir District of South Sumatra Province, Geographically, it is located between $104^{\circ} 50^{\prime} 15^{\prime}$ '- $105^{\circ} 4$ ' $30^{\prime \prime}$ 'E and $3^{\circ} 14^{\prime} 15^{\prime}$ '$3^{\circ} 31^{\prime} 45^{\prime \prime} \mathrm{S}$. The total area of research is $63,427 \mathrm{ha}$. It consists of various land uses, namely secondary forests, oil palm, shrubs, rice fields, grasses and water bodies.

\section{Tools and Research Data}

The tools used in this research were GPS (Global positioning system), digital cameras and laptops with GIS software. The data used in this study was Landsat 8 Satellite Imagery (path/row : 124/62) recorded on August 2018. The data from the field was also collected, including soil moisture with 5 samples of each TVDI level.

\section{Analysis Method}

There were four step analyses, namely: land use, NDVI, LST and TVDI.

1. NDVI Analyses.

The analysis of vegetation density was based on the following calculation :

$$
\text { NDVI }=\frac{\operatorname{NIR}(\text { band 5) }-\mathrm{R} \text { (band 4) }}{\operatorname{NIR}(\text { band 5) } \mathrm{R} \text { (band 4) }}
$$

where: $N D V I=$ Normalize Difference Vegetation Index

$N I R=$ Reflectance value in Near Infrared band.

$$
R=\text { Reflectance value in Red Band }
$$

\section{LST Analyses}

Surface temperature calculations were performed using methods developed by Ziaul and Pal (2016) covering the following stages:

$$
\mathrm{LST}=\mathrm{TB} /\left(1+\left(\lambda^{*} \mathrm{~TB} / \rho\right)^{*} \ln \varepsilon\right)
$$

Note: $\quad L S T=$ Land surface temperature

$T B=$ Brightness temperature

$\lambda=$ Wavelength of emission radians

$(11.5 \mu \mathrm{m})$

$\rho=1.438 * 10^{-2}$

$\varepsilon=$ Land surface emission

\section{TVDI analyses}

The TVDI was constructed by using the relationship between LST and NDVI, where it varies between 0 and 1 and it is higher for dry and

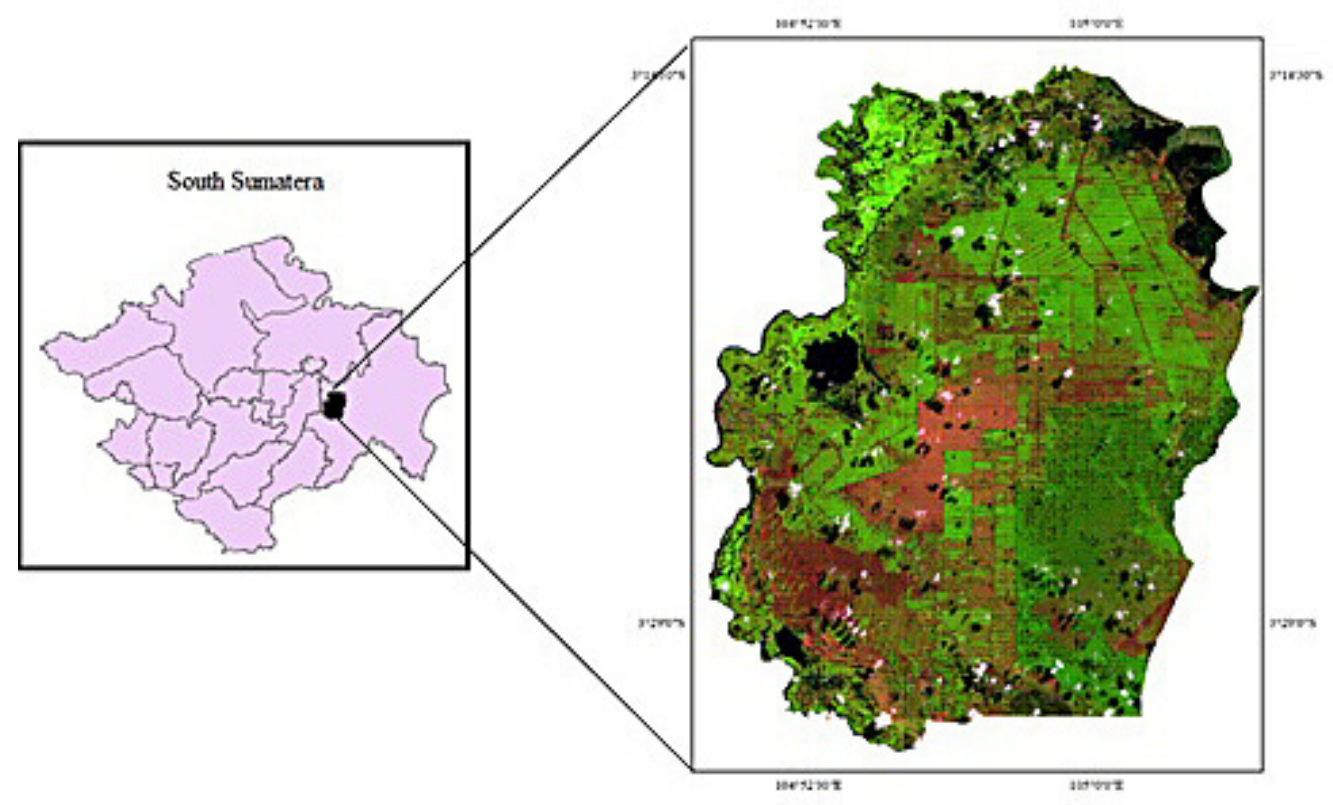

Figure 1. Map of research 
lower for wet conditions (Figure 2). Theoretically, in the triangular figure, the top edge of the triangle indicates zero evapotranspiration and the base edge of the triangle correlated to the NDVI-axis shows the pixels with maximum evapotranspiration. The area between the top and base of the triangle is correlated to evapotranspiration with varying drought condition [Chen et al., 2011].

The dryness index analysis was based on the temperature vegetation dryness index (TVDI) using NDVI value and land surface temperature (LST). TVDI value 1 indicates limited water content, while a value of 0 was sufficient water content.

According Rahimzadeh-Bajgiran and Berg (2016), TVDI formula used is:

$$
\text { TVDI }=\frac{\text { LST }- \text { LSTmin }}{\text { LSTmax }- \text { LSTmin }}
$$

Note: $\quad T V D I=$ Dryness Index

LSTmin = Minimum surface temperature on the triangle, defining the wet side LSTmax = Maximum surface temperature on the triangle, defining the wet side $L S T=$ Surface temperature observed

The criteria of the dryness rate based on TVDI value can be seen in Table 1

Table 1. Dryness rates on land use based on TVDI values [Chen et al. 2011]

\begin{tabular}{|c|l|c|}
\hline No. & \multicolumn{1}{|c|}{ Level of dryness } & TVDI \\
\hline 1 & Extreme wet & $0<$ TVDI $\leq 0.2$ \\
2 & Moderate wet & $0.2<$ TVDI $\leq 0.4$ \\
3 & Normal & $0.4<$ TVDI $\leq 0.6$ \\
4 & Rather dry & $0.6<$ TVDI $\leq 0.8$ \\
5 & Dry & $0.8<$ TVDI $\leq 1.0$ \\
\hline
\end{tabular}

\section{RESULTS AND DISCUSSION}

\section{NDVI and LST}

The spatial distribution of NDVI in the research area was shown in Figure 3 and spatial distribution of LST was shown in Figure 4. The value of NDVI between -0.22 to 0.79 , NDVI with higher value indicates an area with high density and the negative NDVI is flooding. Land surface temperature ranges between $20.37^{\circ} \mathrm{C}$ and $29.44^{\circ} \mathrm{C}$.

The relationship between LST and NDVI (Figure 5) shows that the slope of dry edge is $-14,436$ and slope of wet edge is 0.693 . Chen et al. (2011) stated that slope of dry edge negative indicates that LST or vegetation canopy temperature decrease when vegetation cover increases, while the slope of the wet edge positive indicates that LST or canopy temperature increases along with the crop cover.

\section{TVDI}

The spatial distribution of TVDI is shown in Figure 6. It shows that TVDI with the higher value is a dry area and the smaller value is a wet area. The extreme wet, moderate wet, normal, moderate dry and extreme dry area are 7,185 ha, 19,923 ha, 17,063 ha, 12,644 ha and 6,609 ha, respectively.

Extreme wet area was found on water bodies and forests with high density, moderate wet was found in paddy fields and grass, the normal area in forest land with low density, moderate dry found in oil palm and shrubs and extreme dry found in oil palm with poor management with

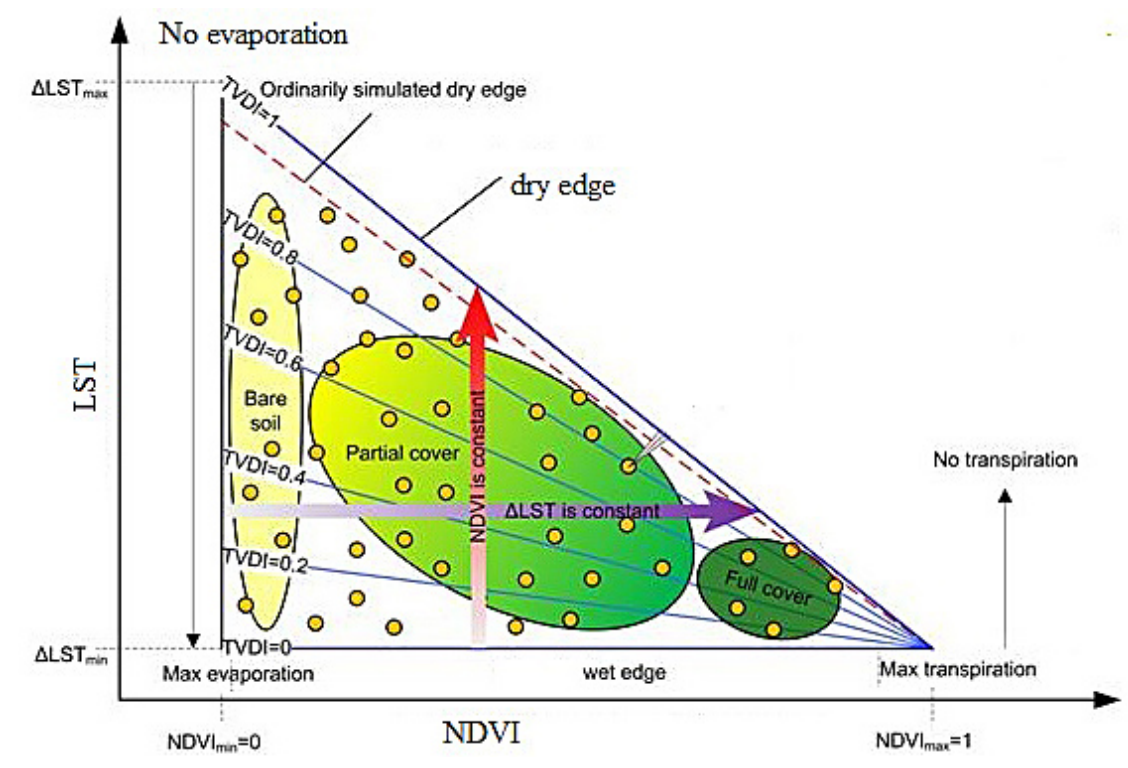

Figure 2. Definition of TVDI [Du et al., 2017] 


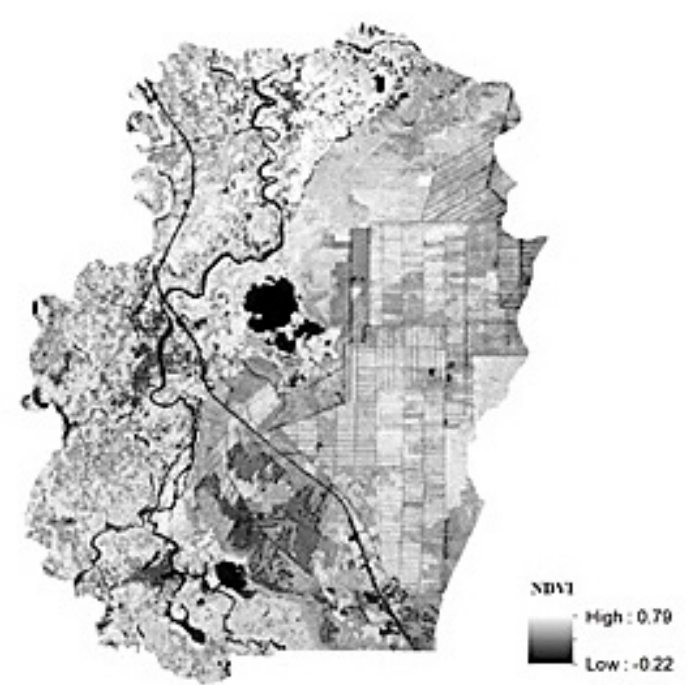

Figure 3. Spatial NDVI

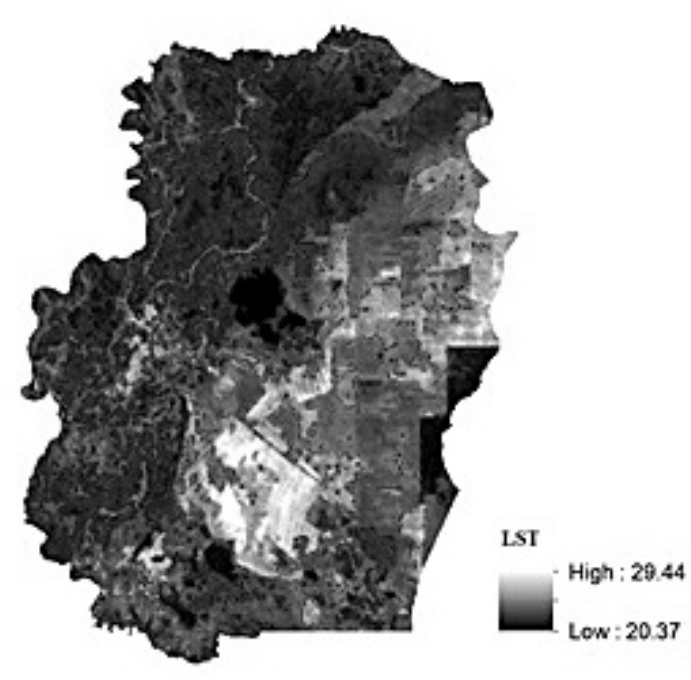

Figure 4. Spatial LST most yellowing leaves (Figure 7). The conversion of forest will influence the quality of peat soil including the soil moisture of each land used [Armanto et al., 2016] and [Junedi et al., 2017]

Water bodies and secondary forests were categorized as extreme wet because these areas have high density with low temperatures and high humidity. This happens because there is high evaporation in the area so that the air temperature will be lower while in the high density forest there is no evaporation but high transpiration from the all parts of the plant. The water from the soil is absorbed by the plant roots and transported to the whole plant. The trees in the forest have long roots so that they can absorb water deeply.

The moderate wet categories are found in paddy fields with rice vegetation and grass with water table depth of about 10 to $20 \mathrm{~cm}$. The condition of shallow water levels causes low humidity on the surface and low air temperature. Although the height of the vegetation is low, it is still available to the roots of the plant; thus, evaporation takes place well.

In the normal area, there is a low density of secondary forests. In this condition, there is an empty distance between the vegetation so that there is excessive evaporation on the empty soil. This causes the area to be higher in temperature compared to forests with high density.

Moderate dry area is found in shrubs and oil palm plantations with good management. Shrubs and oil palm have shallow roots, so the ability to absorb water from the ground is limited. If the water level is far from the ground, the transpiration from plant will decrease

Extremely dry area is found in grasses and oil palm with poor cultivation management. The vegetation in the area has most yellow leaves. Several factors that influence poor plant growth are caused by the environmental factors such as water management and fertilization. Flooding in the area when during the wet season also

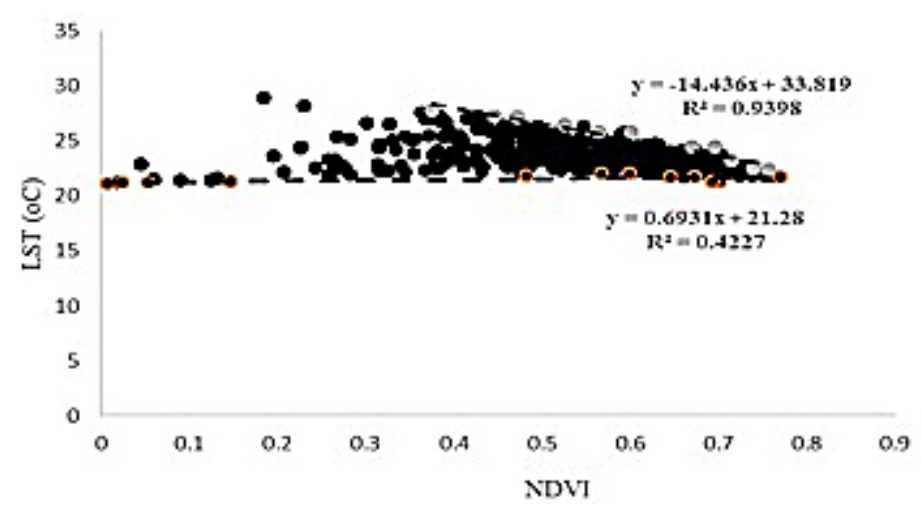

Figure 5. The relationship between LST and NDVI 

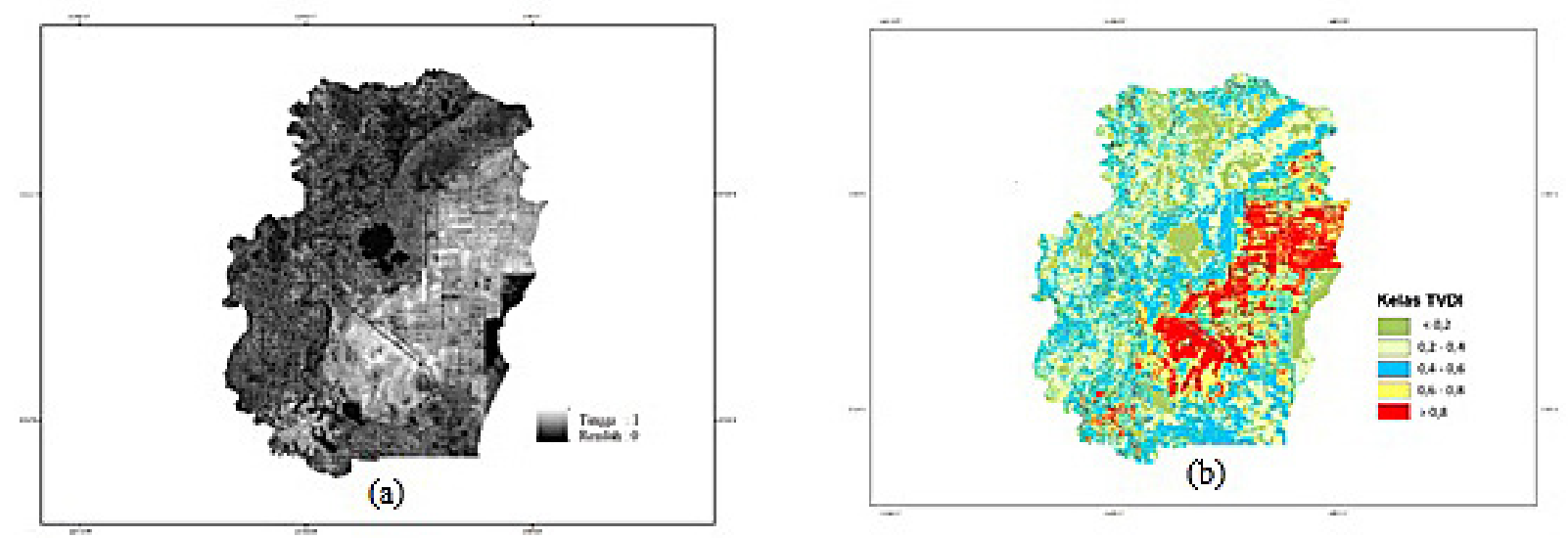

Figure 6. Spatial TVDI

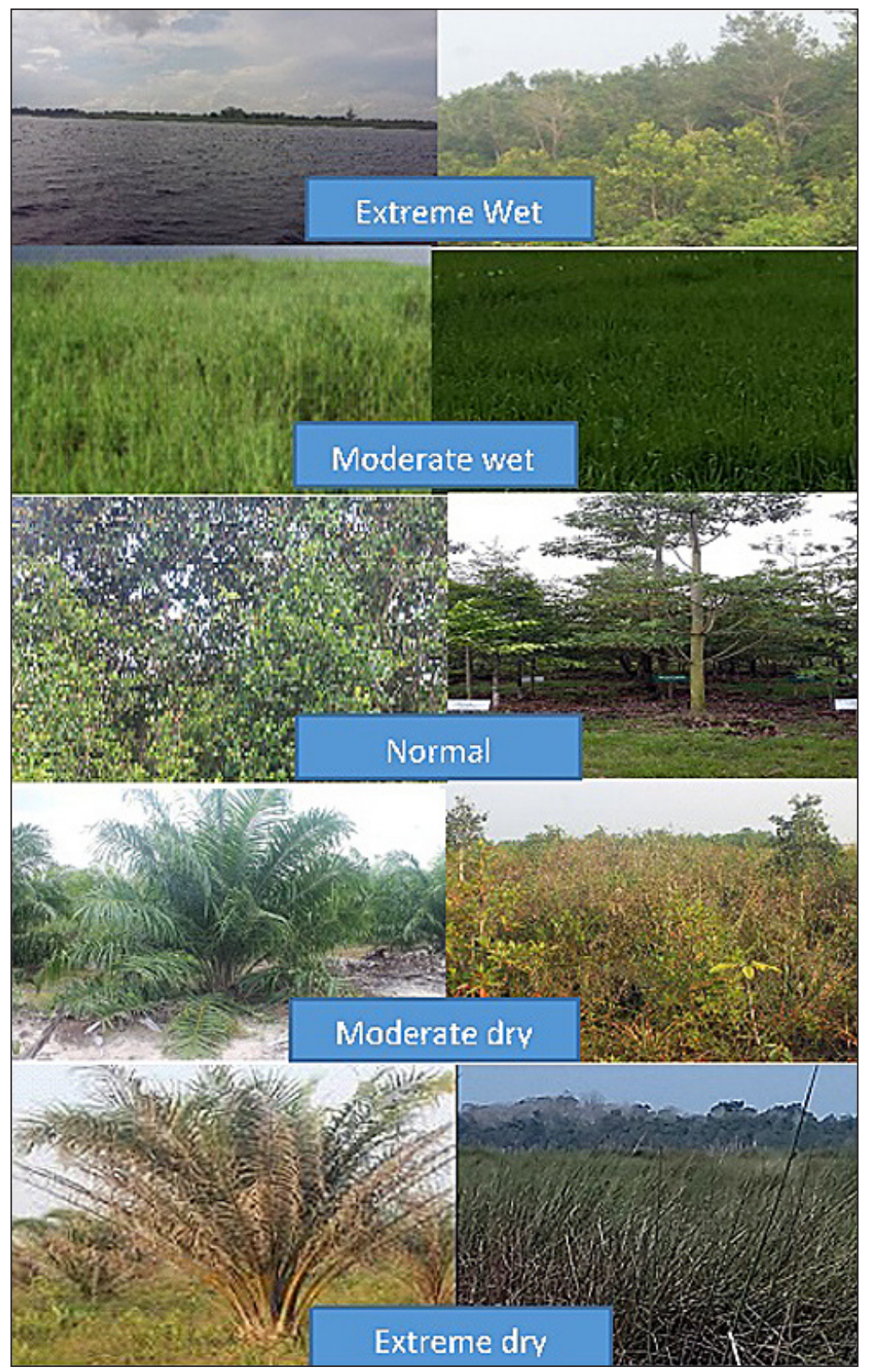

Figure 7. Site condition of each TVDI level 
influences the plant growth and makes the plant grow abnormally.

Oil palms can tolerate flooding, but they do not adapt to long flooding. Under the flooding condition, the roots of the plant are unable to carry out respiration. If flooding continues, the roots may die, water uptake may be disrupted, and flooded palms often appear nitrogen deficient (Corley and Tinker, 2015). Long flooding that lasts for more than one month, causes death of oil palms. During the dry season, a dead plant will dry faster than the live one (Keane, 2015).

\section{Correlation TVDI and soil moisture}

During the wet season, part of the area of the research was flooded and soil moisture reached more than 400 percent; in contrast, in the dry season when rainfall falls under $100 \mathrm{~mm} / \mathrm{month}$, the soil moisture will decrease drastically. The soil moisture in this research was taken in August 2018 during the second month of the dry season. The monthly rainfall in June, July and August 2018 reached $178 \mathrm{~mm}, 43 \mathrm{~mm}$ and $98 \mathrm{~mm}$, respectively.

There is a correlation between the TVDI value and soil moisture at $0-10 \mathrm{~cm}, 10-20 \mathrm{~cm}$ and $20-30$ $\mathrm{cm}$ depth significantly (Figure 8,9 and 10). The soil moisture at $0-10 \mathrm{~cm}, 10-20 \mathrm{~cm}$, and $20-30 \mathrm{~cm}$ depth are 89-189 percent, 112-245 percent and 98 to 250 percent, where the smaller TVDI value corresponds to the higher soil moisture. $\mathrm{R}^{2}$ for $0-10 \mathrm{~cm}, 10-20 \mathrm{~cm}$ and $20-30 \mathrm{~cm}$ depth are $0.6306,0.3865,0.4862$, respectively. TVDI can indicate the soil moisture on the peatland and it would help to draw a map of the fire risk based on soil moisture.

\section{CONCLUSION}

TVDI can classify the level of dryness of peatland and there is the correlation between TVDI and peat soil moisture at $0-10 \mathrm{~cm}, 10-20$ $\mathrm{cm}$, and $20-30 \mathrm{~cm}$ depth. It is important to map the dryness based on TVDI because it will help to control and prevent the fires in the area.

\section{Acknowledgements}

We sincerely appreciate The Indonesian Ministry of Technology, Research and Higher Education (RISTEKDIKTI) for financial support.

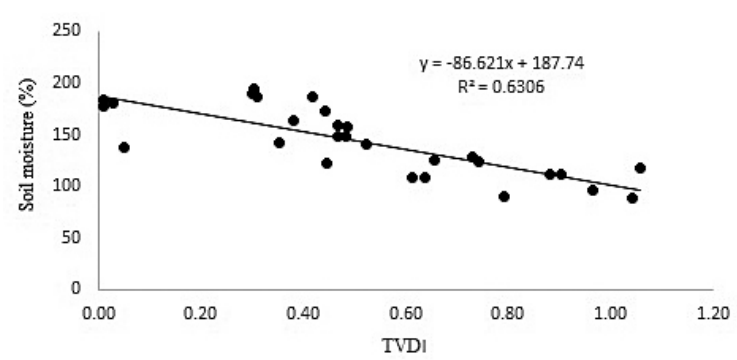

Figure 8. The relationship soil moisture on $0-10 \mathrm{~cm}$ depth and TVDI

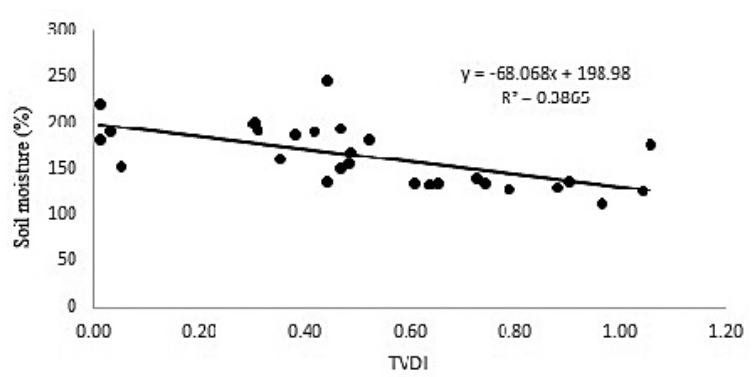

Figure 9. The relationship soil moisture on 10-20 cm depth and TVDI

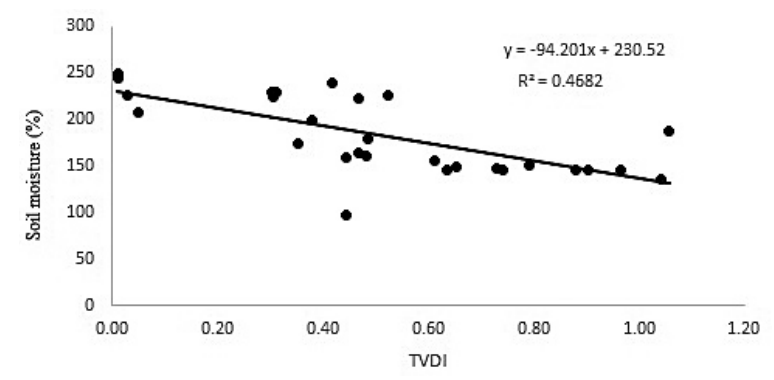

Figure 10. The relationship soil moisture on $20-30 \mathrm{~cm}$ depth and TVDI

\section{REFERENCES}

1. Acharya, T.V. and I. Yang. 2015. Exploring Landsat 8. International Journal of IT, Engineering and Applied Sciences Research (IJIEASR). 4(4), 4-10.

2. Armanto, M.A., E. Wildayana., M.S. Imanudin., H. Junedi., and M.. Zuhdi. 2017. Selected Properties of Peat Degradation on Different Land Uses and the Sustainable Management. Journal of Wetlands Environmental Management 5 (2), 14-22.

3. Arshad, A.M. and M.E. Armanto. 2014. Effect of soil parent material on oil palm yield. Journal of Biology, Agriculture and Healthcare. 4 (10), 4-10.

4. Chen, J., C. Wang., H. Jiang., H. Jiang., L. Mao and Z. Yu. 2011. Estimating soil moisture using Temperature-Vegetation Dryness Index (TVDI) in the Huang-huai-hai (HHH) plain. International Journal of Remote Sensing 32 (4), 1165-1177. 
5. Chen, S., Z. Wen,. H. Jiang., Q. Zhao, X. Zhang and Y. Chen. 2015. Temperature Vegetation Dryness Index Estimation of Soil Moisture under Different Tree Species. Sustainability. 7, 11401-11417.

6. Corley, R.H.V. and P.B. Tinker. 2016. The oil palm. Fifth edition. Wiley Blackwell, UK.

7. Du, L., N. Song., Ke Liu, J. Hou., Yue Hu., Y. Zhu., X. Wang., L. Wan and Y. Gou. 2017. Comparison of Two Simulation Methods of The Temperature Vegetation Dryness Index (TVDI) for Drought Monitoring in Semi-Arid Regions of China. MDPI Remote Sensing Journal 9 (2), 1-9.

8. Englhart, S.; Jubanski and Siegert, F. 2013 Quantifying Dynamics in Tropical Peat swamp Forest Biomass with Multi-Temporal LiDAR Datasets. Remote sensing (5), 2368-2388

9. Holidi, Hermanto dan D. Irawanto. 2014. The Growth of Palm Oil (Elaeis guineensis Jacq.) Seedlings on Peat Soil Media in Various of Water Table. Prosiding Seminar Nasional Lahan Suboptimal 2014. 26-27 September 2014. Palembang. Hal. 112- 118.

10. Holidi, Etty Safriyani, Warjiyanto dan Sutejo. 2015. The Growth of Oil Palm Seedling on Peat Soil in Various of Flooding Height. Jurnal Ilmu Pertanian 18 (3), 135-140.

11. Hoojier, A., Page S., Jauhiainen J., Lee WA., Idris A., Anshari G. 2012. Subsidence and Carbon Loss in Drained Tropical Peatlands. Biogeosciences. 9, 1053-1071.

12. Junedi, H,; M. E. Armanto, S. Bernas, and M. Imanudin. 2017. Changes to Some Physical Prop- erties due to Conversion of Secondary Forest of Peat into Oil Palm Plantation. Sriwijaya Journal of Environment 2 (3), 76-80.

13. Keane, R.E. 2015. Wildland fuel fundamentals and applications. Springer Cham Heidelberg New York Dordrecht, London.

14. Kirana, A.P., I.S. Sitanggang and L. Syaufina. 2016. Hotspot pattern distribution in peatland area in $\mathrm{Su}-$ matra based on spatio temporal clustering. The 2 nd International Symposium on LAPAN-IPB Satellite for Food Security and Environmental Monitoring 2015, LISAT-FSEM 2015. Procedia Environmental Sciences (33), 635-645.

15. Lim, K.H., Lim, S.S., Parish. F. And Suharto, R. 2012. RSPO Manual on best management practices (BMPs ) forexisting oil palm cultivation on peat. RSPO,Kuala Lumpur.

16. Miettinen, J. And S.C. Liew. 2010. Status of peatland degradation and development in Sumatra and Kalimantan. Journal Ambio 39, 394-401.

17. Osaki, M., K. Hirose., H.Segah and F. Felmy. 2016. Tropical peatland and peatland definition in Indonesia in Tropical Peatland Ecosystem. Springer, Sapporo. Japan

18. Rahimzadeh P. and Berg, A. 2016. Chapter 3- Soil Moisture Retrievals Using Optical/TIR Methods. Journal Satellite Soil Moisture Retrival, 47-72.

19. Schirmbeck, L.W, D.C. Fontana, J. Schirmbeck, V.P. Mengue. 2017. Understanding TVDI as an index that expresses soil moisture. Journal of Hyperspectral Remote Sensing 7 (2), 82-90. 